\title{
Disqualification of Federal Judges for Bias or Prejudice
}

That judges must be fair is axiomatic; guaranteeing that fairness is a stubborn and persistent problem. Congress and the federal courts have attempted to impose workable safeguards of impartiality by statute since $1792^{1}$ and by ethical code since $1924 .^{2}$ Both the statutory scheme and the Code of Judicial Conduct have recently been amended, largely because of a heightened demand for fairness-and the appearance of fairness-in the nation's tribunals. ${ }^{3}$ Although it is now easier for a litigant to have a federal judge disqualified for bias or prejudice, the current scheme falls considerably short of providing a complete solution to the problems of judicial bias and prejudice. ${ }^{4}$ Indeed, both substantive and procedural problems have arisen that may make the current disqualification scheme vulnerable to manipulation by unscrupulous litigants.

The substantive problems have generally involved the adequacy of an allegation of bias or prejudice: Does the mere appearance of bias justify disqualification? Does the reasonable litigant's fear of judicial bias or prejudice mandate disqualification? Must disqualifying bias be extrajudicial? Does a judge's bias against

1 Act of May 8, 1792, ch. 36, $\S 11,1$ Stat. $278-79$ (codified at 28 U.S.C. $\S 455$ (1976)).

2 ABA Canons of Judicial Etrics No. 4 (1924).

3 For an account of the recent controversies over judicial ethics, see J. Mackenzie, The Appearance of Justice (1974). See also R. Shogun, A Question of Judgment: The Fortas CASE aNd the Struggle for the Supreme Court (1972).

1 On disqualification for bias, see Schwartz, Disqualification for Bias in the Federal District Court, 11 U. PrTr. L. REv. 415 (1950); Comment, The Elusive Appearance of Propriety: Judicial Disqualification Under Section 455, 25 De PaUl L. REv. 104 (1975); Note, Disqualification of Federal Judges for Bias Under 28 U.S.C. Section 455, 45 FoRDHAM L. REv. 139 (1976); Note, Disqualification of Judges for Bias in the Federal Courts, 79 Harv. L. REv. 1435 (1966); Note, Disqualification of a Federal District Judge for Bias-The Standard Under Section 144, 57 Mins. L. REv. 749 (1973) [hereinafter cited as Minnesota Note]; Note, Disqualification of Judges for Bias or Prejudice-A New Approach, 1972 UTAH L. Rev. 448. On disqualification for interest, see Comment, Disqualification for Interest of Lower Federal Court Judges: 28 U.S.C. $\$ 455,71$ Мich. L. REv. 538 (1978). On the disqualification statutes in general, see Frank, Commentary on Disqualification of Judges-Canon 3C, 1972 UTAн L. REv. 377; Frank, Disqualification of Judges, 56 YALE L.J. 605 (1947); Frank, Disqualification of Judges: In Support of the Bayh Bill, 35 LAw \& ConTEMP. ProB. 43 (1970); Orfield, Recusation of Federal Judges, 17 Bufralo L. REv. 799 (1968); Note, Disqualification of Judges and Justices in the Federal Courts, 86 HARv. L. REv. 736 (1973) [hereinafter cited as Harvard Note]; Comment, Disqualification of Federal District Judges-Problems and Proposals, 7 Seton Hall L. REv. 612 (1976); Note, Disqualification of Federal Judges-The Need for Better Guidelines, 13 WAKe Forest L. Rev. 353 (1977). See also 13 C. Wright, A. MrLleR \& E. Cooper, Federal Practice and Procedure $\$ \S 3541-3553$ (1975) [hereinafter cited as WRIGHT \& MILLER]. 
counsel mandate disqualification? For the most part, the procedural problems have centered on three specific issues: express waiver of a litigant's right to have a judge disqualified, timeliness requirements on motions to disqualify, and transfer of disqualification motions to another tribunal. This comment proposes a resolution of these substantive and procedural problems that minimizes the risks of abuse of judicial disqualification while recognizing the value of a liberalized disqualification process.

\section{The Framework of Federal Judicial Disqualification}

The federal law governing judicial disqualification ${ }^{5}$ is embodied in sections 144 and 455 of the Judicial Code. ${ }^{6}$ Section $144^{7}$ requires

5 This comment will uniformly use the word "disqualification" when referring to disqualification or recusal, even though "disqualification" technically refers to mandatory standing down under a statute and "recusal" refers to voluntary standing down. Frank, Disqualification of Judges: In Support of the Bayh Bill, supra note 4, at 45. Under current statutes, disqualification is mandated in virtually all cases where recusal is appropriate.

- 28 U.S.C. $\$ \S 144,455$ (1976). The Constitution also sets standards which may require a judge's disqualification. The due process clauses of the fifth and fourteenth amendments require a "fair trial in a fair tribunal." In re Murchison, 349 U.S. 133, 136 (1955). The Supreme Court has said, moreover, that "to perform its high function in the best way "justice must satisfy the appearance of justice." "Id. (quoting Offutt v. United States, 348 U.S. 11, 14 (1954)).

Under some circumstances, therefore, the Constitution may demand that an apparently biased judge be disqualified. The stringency of the constitutional standard is not well defined, however, because the subject of judicial disqualification in the federal courts is governed by statutes that establish a more stringent standard than the Constitution demands. United States v. Haldeman, 559 F.2d 31, 130 n.276 (D.C. Cir. 1976) (en banc) (per curiam), cert. denied, 431 U.S. 933 (1977). The Supreme Court's pronouncements on judicial disqualification in.the federal courts, therefore, have generally been interpretations of the Judicial Code. See, e.g., United States v. Berger, 255 U.S. 22 (1921). The Supreme Court has never reversed a federal judge on due process grounds for failure to disqualify himself. $C f$. Tumey v. Ohio, 273 U.S. 510 (1927) (holding that the trial of the defendant by the local mayor who was to be compensated for his judicial services only if the defendant were convicted, violated due process). In interpreting congressional enactments on the subject, however, courts and counsel should bear in mind that there is a level of guarantee of fairness below which Congress may not go. The federal courts have applied due process to the problem of disqualification upon review of state court cases, see, e.g., Ward v. Village of Monroeville, 409 U.S. 57 (1972); Mayberry v. Pennsylvania, 400 U.S. 455 (1971), upon habeas corpus, see, e.g., United States ex rel. Perry v. Cuyler, 584 F.2d 644 (3d Cir. 1978), and upon review of egregious conduct, see, e.g., Reserve Mining Co. v. Lord, 529 F.2d 181 (8th Cir. 1976).

7 Section 144 provides:

Whenever a party to any proceeding in a district court makes and files a timely and sufficient affidavit that the judge before whom the matter is pending has a personal bias or prejudice either against him or in favor of any adverse party, such judge shall proceed no further therein, but another judge shall be assigned to hear such proceeding.

The affidavit shall state the facts and the reasons for the belief that bias or prejudice exists, and shall be filed not less than ten days before the beginning of the term at which the proceeding is to be heard, or good cause shall be shown for failure to file it within such time. A party may file only one such affidavit in any case. It shall be accompanied 
the disqualification of a district court judge upon the timely filing of an affidavit by a party averring that the judge has a "personal bias or prejudice" against him or in favor of the other party. Although the affidavit must state "the facts and the reasons" for the averment of prejudice, the judge may not rule on the truth or falsehood of the allegations. If sufficient to support an inference of bias, the averment must be accepted as true, and the judge must step down. ${ }^{8}$

Section $455,{ }^{9}$ prior to its amendment in 1974 , required a federal judge to disqualify himself in certain specified situations in which he had a "substantial interest" in the outcome of the case, or where, "in his opinion," he was so related to a party or an attorney as to render his participation "improper." The statute was viewed as selfenforcing: the parties were not required to submit motions or affidavits, although they were permitted to do so. ${ }^{10}$ Disqualification in the specifically defined instances was mandatory; disqualification because of impropriety was discretionary. ${ }^{11}$ If a judge wrongly failed to disqualify himself, various forms of review were available. ${ }^{12}$

By the early 1970 s this statutory framework was widely viewed as inadequate. Section 144 , which had originally been conceived of as a form of peremptory challenge, ${ }^{13}$ was limited in application by

by a certificate of counsel of record stating that it is made in good faith.

28 U.S.C. § 144 (1976).

\& See Wright \& MiLLER, supra note 4, § 3551, at 381. The affidavit must state facts and reasons for the averment of prejudice with particularity as to time, place, persons, and circumstances. It must be sworn to or affirmed by a party, and accompanied by a certificate of good faith from counsel. It must be timely. A party is limited to one affidavit of prejudice in a given case. $I d$. at 375-81.

Some courts have stated that the affidavit may not contain hearsay. See United States v. Haldeman, 559 F.2d 31, 135 \& n.317 (D.C. Cir. 1976) (en banc) (per curiam), cert. denied, 431 U.S. 933 (1977), and cases cited therein. It is difficult to reconcile this with the requirement that the allegations be accepted as accurate. The fact that the allegation is supported by hearsay should make no difference since it need not be supported by evidence at all.

- Prior to the 1974 amendments, section 455 provided:

Any justice or judge of the United States shall disqualify himself in any case in which he has a substantial interest, has been of counsel, is or has been a material witness, or is so related to or connected with any party or his attorney as to render it improper, in his opinion, for him to sit on the trial, appeal, or other proceeding therein.

28 U.S.C. \& 455 (1970).

10 Wright \& Miller, supra note $4, \S 3550$, at 372-73.

" Harvard Note, supra note 4, at 738-39.

12 See, e.g., Parrish v. Board of Comm'rs, 524 F.2d 98 (5th Cir. 1975) (en banc) (appeal from final judgment), cert. denied, 425 U.S. 944 (1976); Davis v. Board of School Comm'rs, 517 F.2d 1044 (5th Cir. 1975) (interlocutory appeal), cert. denied, 425 U.S. 944 (1976); Texaco, Inc. v. Chandler, 354 F.2d 655 (10th Cir. 1965) (per curiam) (mandamus).

is Parrish v. Board of Comm'rs, 524 F.2d 98, 106 (5th Cir. 1975) (en banc) (Roney, J., specially concurring), cert. denied, 425 U.S. 944 (1976). The chief sponsor of the bill that became the forefunner of section 144, Act of Mar. 3, 1911, ch. 231, $\S 20,21,3$ Stat. 1090, 
the requirement of personal "bias in fact"14 and by the conception that, in a close case, a judge had a "duty to sit." 15 Courts had held that a supporting affidavit must be strictly construed against the party seeking disqualification. ${ }^{16}$ The affidavit procedure was also perceived as weakening the effect of the statute: counsel would be wary of antagonizing the judge by such a direct attack upon his fairness. ${ }^{17}$ Section 455 was also regarded as ineffectual. The requirement of "substantial interest" was ill-defined ${ }^{18}$ and could result in failure to disqualify even in the face of a judge's financial interest in a litigant. ${ }^{19}$ The specific mandatory grounds for disqualification were narrowly construed, and the discretionary ground rarely had bite. ${ }^{20}$

In response to the growing criticism of the disqualification statutes, an American Bar Association committee drafted a new Code of Judicial Conduct that included a canon governing disqualification. ${ }^{21}$ The canon, which was intended to be a self-enforcing disqualification provision, provided for disqualification in situations involving bias or interest. It was adopted by the Judicial Conference of the United States ${ }^{22}$ and enacted by Congress, with minor changes, as amended section $455^{23}$ of the Judicial Code. Section 455 , as

stated that the judge retained no discretion after the filing of the affidavit of prejudice: the judge could proceed no further in the case. 46 CoNG. REc. 2627 (1911) (statement of Rep. Cullop).

"See, e.g., Wolfson v. Palmieri, 396 F.2d 121, 124 (2d Cir. 1968) (per curiam) ("To be sufficient, an affidavit [for disqualification of a judge] must show the objectionable inclination or disposition or impede impartiality of judgment."). See also Pfizer, Inc. v. Lord, 456 F.2d 532, 537 (8th Cir.), cert. denied, 406 U.S. 976 (1972); Minnesota Note, supra note 4.

1s See, e.g., United States v. Diorio, 451 F.2d 21, 24 (2d Cir. 1971), cert. denied, 405 U.S. 955 (1972); Edwards v. United States, 334 F.2d 360, 362 n.2 (5th Cir. 1964).

"See, e.g., Beland v. United States, 117 F.2d 958, 960 (5th Cir. 1941).

17 See Frank, Disqualification of Judges: In Support of the Bayh Bill, supra note 4, at 65.

is See E. Thode, Reporter's Notes to the ABA Code of Judicial Conduct 65 (1973) [hereinafter cited as REPORTER's NoTES].

"See, e.g., Kinnear-Weed Corp. v. Humble Oil \& Refining Co., 403 F.2d 437 (5th Cir. 1968), cert. denied, 404 U.S. 941 (1971).

- See generally Harvard Note, supra note 4, at 740-42.

21 ABA Code of Judictal Conduct, Canon 3 (1972). See Reporter's Notes, supra note 18.

2 See 69 F.R.D. 273, 277 (1975). For a brief history of the Judicial Conference, see Burger, The Courts on Trial, 22 F.R.D. 71 (1968). See also 73 F.R.D. 247 (1976).

2s Section 455 now provides, in part:

(a) Any justice, judge magistrate, or referee in bankruptcy of the United States shall disqualify himself in any proceeding in which his impartiality might reasonably be questioned.

(b) He shall also disqualify himself in the following circumstances:

(1) Where he has a personal bias or prejudice concerning a party, or personal knowledge of disputed evidentiary facts concerning the proceeding; 
amended, provides that a judge "shall disqualify himself in a proceeding in which his impartiality might reasonably be questioned." ${ }_{24}$ It then lists specific situations in which a judge must

(2) Where in private practice he served as lawyer in the matter in controversy, or a lawyer with whom he previously practiced law served during such association as a lawyer concerning the matter, or the judge or such lawyer has been a material witness concerning it;

(3) Where he has served in governmental employment and in such capacity participated as counsel, adviser or material witness concerning the proceeding or expressed an opinion concerning the merits of the particular case in controversy;

(4) He knows that he, individually or as a fiduciary, or his spouse or minor child residing in his household, has a financial interest in the subject matter in controversy or in a party to the proceeding, or any other interest that could be substantially affected by the outcome of the proceeding;

(5) He or his spouse, or a person within the third degree of relationship to either of them, or the spouse of such a person:

(i) Is a party to the proceeding, or an officer, director, or trustee of a party;

(ii) Is acting as a lawyer in the proceeding;

(iii) Is known by the judge to have an interest that could be substantially affected by the outcome of the proceeding;

(iv) Is to the judge's knowledge likely to be a material witness in the proceeding.

(e) No justice, judge magistrate, or referee in bankruptcy shall accept from the parties to the proceeding a waiver of any ground for disqualification enumerated in subsection (b). Where the ground for disqualification arises only under subsection (a), waiver may be accepted provided it is preceded by a full disclosure on the record of the basis for disqualification.

28 U.S.C. \& 455 (1976).

The statute changed the generic word "judge" used in the Code to the more specific "justice, judge, magistrate, or referee in bankruptcy." It substituted the word "shall" for the word "should," thereby emphasizing the mandatory character of the provision. It introduced the specific grounds for disqualification in subsection (b) as separate and independent grounds, whereas the Code listed them as examples of instances where a judge's "impartiality might reasonably be questioned." It added a new specific ground for disqualification-subsection (b)(3) - to regulate the conduct of judges recently employed by the government. Finally, the statute deviated from Canon 3D by permitting waiver of disqualification based on subsection (a) while disallowing waiver based on the specific grounds of subsection (b). Canon 3D-now repealed, see note 139 infra-disallowed waiver in the event of an appearance of partiality, but permitted it where "the judge's relationship is immaterial or . . . his financial interest is insubstantial." Compare 28 U.S.C. $\$ 455$ (1976) with ABA CoDE of Judicial Conduct, Canon 3 (1972).

The Code and the Reporter's Notes, supra note 18, are therefore reliable sources for interpretation of congressional intent in revising section 455 . One of the principal purposes of the revision was to make the statute "conform" to the Code, and thus to eliminate the "dual standards, statutory and ethical," that "had the effect of forcing a judge to decide either the legal issue or the ethical issue at his peril." H.R. REP. No. 1453, 93d Cong., 2d Sess. 2 (1974), reprinted in [1974] U.S. CoDE Cong. \& AD. NEws at 6351-52 [hereinafter cited as House REport]. See Virginia Elec. \& Power Co. v. Sun Shipbuilding \& Dry Dock Co., 407 F. Supp. 324, 327 n. 8 (E.D. Va.) (calling the Reporter's Notes "the only authoritative clue as to the intent behind the language of the Code's provisions."), vacated on other grounds, 537 F.2d 357 (3d Cir. 1976).

24 See note 23 supra. 
disqualify himself. Among these is a proceeding in which the judge "has a personal bias or prejudice concerning a party, or personal knowledge of disputed evidentiary facts concerning the proceeding." 25

Congress's initial goal in amending section 455 was to eliminate the concepts of "duty to sit" and "substantial interest." ${ }^{26}$ Congress was critical of the judicial gloss on the old statute that urged a judge to sit when faced with a close question of disqualification. By eliminating the "duty to sit," Congress hoped to "enhance public confidence in the impartiality of the judicial system." 27 By defining "financial interest" in section $455(\mathrm{~b})(4)$ as any legal or equitable interest "however small," Congress intended to avoid the "uncertainty and ambiguity about what is a 'substantial' interest." ${ }^{28}$ In addition, Congress intended to replace the subjective stan-

${ }^{25}$ See note 23 supra.

24 See House RePORT, supra note 23, at 2, 5, reprinted in [1974] U.S. CODE CoNG. \& AD. NEws at 6352, 6355. Despite the clarity of the congressional purpose to eliminate the duty to sit, many courts have continued to find some version of such a duty. See, e.g., United States v. Bray, 546 F.2d 851, 857 (10th Cir. 1976); Smith v. Danyo, 441 F. Supp. 171, 175 (M.D. Pa. 1977); Honneus v. United States, 425 F. Supp. 164, 166 (D. Mass. 1977); United States v. Sinclair, 424 F. Supp. 715, 719 (D. Del. 1976); Andrews, Mosburg, Davis, Elam, Legg \& Bixler, Inc. v. General Ins. Co., 418 F. Supp. 304, 307 (W.D. Okla. 1976); United States v. Pastor, 419 F. Supp. 1318, 1332 (S.D.N.Y. 1975); Hirschkop v. Virginia State Bar Ass'n, 406 F. Supp. 721, 725 (E.D. Va. 1975); Sperry Rand Corp. v. Pentronix, Inc., 403 F. Supp. 367, 373 (E.D. Pa. 1975); Hall v. Burkett, 391 F. Supp. 237, 240 (W.D. Okla. 1975). Courts typically accomplish this by shifting the burden of proof to the party seeking disqualification. "The judge is presumed to be qualified, and there is a substantial burden upon the movant to show that such is not the case." United States v. Zagari, 419 F. Supp. 494, 501 (N.D. Cal. 1976).

Some courts have admitted that Congress intended to eliminate the "duty to sit," but nevertheless have attempted to articulate a limited version of the duty. See, e.g., Simonson v. General Motors Corp., 425 F. Supp. 574, 579 (E.D. Pa. 1976); Duplan Corp. v. Deering Milliken, Inc., 400 F. Supp. 497, 526-27 (D.S.C. 1975); Lazofsky v. Sommerset Bus Co., 389 F. Supp. 1041, 1044-45 (E.D.N.Y. 1975).

It might be argued that the "duty to sit" is ended under section 455 , but continues under section 144. This would, at times, create a direct conflict between the statutes: section 144 would require the judge to sit, and section 455 would require him to stand down. In the event of such conflict, the clear legislative intent should take precedence over the rejected judicial gloss. Most courts have acknowledged that the "duty to sit" has been abolished. See, e.g., United States v. Wolfson, 558 F.2d 59, 63 (2d Cir. 1977); United States v. Haldeman, 559 F.2d 31, 139 n.360 (D.C. Cir. 1976) (en banc) (per curiam), cert. denied, 431 U.S. 933 (1977); Davis v. Board of School Comm'rs, 517 F.2d 1044, 1052 (5th Cir.), cert. denied, 425 U.S. 944 (1975); Hawaii-Pacific Venture Capital Corp. v. Rothbard, 437 F. Supp. 230, 234 (D. Hawaii 1977); Smith v. Pepsico, Inc., 434 F. Supp. 524, 526 n.2 (S.D. Fla. 1977); Fong v. American Airlines, Inc., 431 F. Supp. 1334, 1337 (N.D. Cal. 1977); Bradley v. Milliken, 426 F. Supp. 929, 933 (E.D. Mich. 1977); Mavis v. Commercial Carriers, Inc., 408 F. Supp. 55, 61 (C.D. Cal. 1975); Samuel v. University of Pittsburgh, 395 F. Supp. 1275, 1277 n.3 (W.D. Pa. 1975), vacated on other grounds, 538 F.2d 991 (3d Cir. 1976).

${ }^{21}$ House RePort, supra note 23, at 6, reprinted in [1974] U.S. Code Cong. \& AD. News at 6356. 
dard of the prior section 455 , which required disqualification when necessary "in [the judge's] opinion," with an objective standard that demanded disqualification when the judge's "impartiality might reasonably be questioned." ${ }_{29}$ Moreover, these effects were not intended to be exclusive; language in the legislative history evinces a general purpose to "broaden and clarify the grounds for judicial disqualification." 30 The task of actually giving effect to this general change in the scope and purpose of federal judicial disqualification was, however, left to the courts.

Section 144 and section 455 originally addressed different issues: disqualification for bias and disqualification for interest, respectively. ${ }^{31}$ The 1974 amendment to section 455 , however, created substantial-and conflicting-overlap in the statutory scheme. If a litigant has reason to believe that the district judge ${ }^{32}$ is biased against him or in favor of his adversary, his motion for disqualification may be governed by any of three different statutory provisions: the unamended section 144, the general provisions of amended section $455(\mathrm{a})$, or the specific provisions of amended section $455(\mathrm{~b})$. The resulting difficulties in interpreting these provisions are the subject of the remainder of this comment.

\section{The Factual Basis of Disqualification for Bias or Prejudice}

\section{A. The Standard of Proof}

Under section 144 and, since the 1974 amendment, under section 455 , the federal courts have grappled with the problem of how substantial allegations of bias or prejudice must be to necessitate disqualification. The inquiry is inherently more demanding when the factual basis for disqualification is bias rather than interest because, while the latter turns on ascertaining objective facts, the former inevitably requires an evaluation of the judge's state of mind. The two principal competing standards of proof are the appearance-of-bias test-the allegations need only be sufficient to support a reasonable apprehension of bias-and the bias-in-fact

2 Id. at 5, reprinted in [1974] U.S. CoDE CoNG. \& AD. News at 6354-55.

30 Id. at 1, reprinted in [1974] U.S. CoDE CoNG. \& AD. NEws at 6351 (emphasis added).

"1 Prior to the amendments of 1974 , section 455 and section 144 partially overlapped insofar as a judge's connection with a party or an attorney was the source of bias or prejudice. In such a case both section 455 and section 144 could have supported a motion for disqualification. See notes 7-8 supra.

32 Section 144 applies only to federal district judges; amended section 455 applies to all Justices, judges, magistrates, and referees in bankruptcy in the federal courts. If the judge sought to be challenged is other than a district judge, the movant's only statutory protection is section 455 . 
test-the allegations must be sufficient to support a conclusion that bias actually exists. The obvious distinction between the two tests lies in their differing evidentiary burdens, with the bias-in-fact test requiring the more substantial showing. ${ }^{33}$

1. The Standard Under Section 144. The language of section 144 does not explicitly endorse either the bias-in-fact or the appearance-of-bias test, although it does appear most compatible with the bias-in-fact standard. ${ }^{34}$ The party must allege that the judge has the bias and must present facts and reasons for a belief that the bias exists. It is not a precise reading of the statute, however, to foreclose the conclusion that the allegations need only support an apprehension of bias. ${ }^{35}$ The legislative history of section 144 is similarly inconclusive. The enacting Congress plainly desired to remove most discretion from judges by giving peremptory effect to a sufficient affidavit. ${ }^{36}$ It does not follow, however, that the affidavit should allege anything less than bias in fact. Given the inconclusive guidance of the statutory language and legislative history, and the absence of any obligation to support factually allegations of bias, the federal courts have consistently found it reasonable to require that the allegations-taken as true-fairly support a conclusion that bias exists. ${ }^{37}$

Prior to the 1974 amendment of section 455, some commentators unsuccessfully argued that the judicially imposed bias-in-fact standard should be replaced by an appearance-of-bias test. ${ }^{38}$ Following the 1974 amendment to section 455 , some judges have renewed the call for a reexamination of the proper standard of proof under section $144 .^{30}$ This issue recently split the Fifth Circuit, sitting en banc in Parrish v. Board of Commissioners. ${ }^{40}$

${ }^{33}$ One commentator has equated the bias-in-fact test with a preponderance-of-theevidence test. The appearance-of-bias test would require "some quantum of evidence less than that necessary for proof of a fact." Minnesota Note, supra note 4, at 759-60.

"See the text of section 144 reproduced at note 7 supra.

${ }^{35}$ See Minnesota Note, supra note 4, at 763-70; Note, Disqualification of Judges for Bias in the Federal Courts, supra note 4, at 1446.

36 See text and notes at notes 7-8 supra.

${ }^{37}$ See, e.g., Bell v. Chandler, 569 F.2d 556, 559 (10th Cir. 1978); United States v. Daley, 564 F.2d 645, 651 (2d Cir. 1977), cert. denied, 435 U.S. 933 (1978); United States v. Haldeman, 559 F.2d 31, 130 (D.C. Cir. 1976) (en banc) (per curiam), cert. denied, 431 U.S. 933 (1977); United States v. Bray, 546 F.2d 851, 857 (10th Cir. 1976); Mims v. Shapp, 541 F.2d 415, 417 (3d Cir. 1976); United States v. Baker, 441 F. Supp. 612, 616 (M.D. Tenn. 1977); Smith v. Danyo, 441 F. Supp. 171, 175 (M.D. Pa. 1977); Roussel v. Tidelands Capital Corp., 438 F. Supp. 684,690 (N.D. Ala. 1977).

38 See Note, Disqualification of Judges for Bias in the Federal Courts, supra note 4, at 1446-47; Minnesota Note, supra note 4, at 763-70.

3 See Parrish v. Board of Comm'rs, 524 F.2d 98, 108 (5th Cir. 1975) (en banc) (Tuttle, Goldberg, JJ., dissenting), cert. denied, 425 U.S. 944 (1976).

- 524 F.2d 98 (5th Cir. 1975) (en banc), cert. denied, 425 U.S. 944 (1976). 
In Parrish, a suit alleging racial discrimination in the administration of the Alabama bar examination, plaintiffs moved for disqualification of the trial judge under section 144. Plaintiffs filed an affidavit claiming that the judge had recently been president of the Montgomery County Bar Association, which had excluded blacks from membership during his tenure, and that he knew and would grant credibility to the testimony of most of the defendants. ${ }^{41}$ The judge refused to disqualify himself. A panel of the Fifth Circuit reversed on the disqualification issue..$^{42}$ The case was complicated by the fact that amended section 455 went into effect between the date of the panel decision and the date of the en banc decision. Neither the district court nor the panel had the opportunity to make findings or a ruling under the amended statute. Nevertheless, the Fifth Circuit, en banc, affirmed the district judge's refusal to disqualify himself under both section 144 and new section $455 . .^{43}$

The majority segregated its discussions of sections 144 and 455 . It did not reinterpret section 144 in the light of the revisions of section 455 . Instead, the court retained the established judicial gloss on section 144 and applied a bias-in-fact test. Under that test the court found that the plaintiffs' affidavits failed to support the charge of bias. ${ }^{44}$ The dissenters, on the other hand, insisted that the statutory provisions imposed an appearance-of-bias standard..$^{45}$

The Parrish dissenters based their arguments upon the language of section 144 and the legislative history of amended section 455. Under section 144 , the affidavit of prejudice must state the reasons for the belief that bias or prejudice exists. "For the belief" implies, the dissenters argued, that the appearance of bias should

4 Id. at 101.

12 Id. at 99-101.

4s Id. at 102-03. The revisions of section 455 were not to "apply to the trial of any proceeding commenced prior to the date of this Act, nor to appellate review of any proceeding which was fully submitted to the reviewing court prior to the date of this Act." Pub. L. No. 93-512, \& 3, 88 Stat. 1609 (1974). The plain meaning of this provision is that the new standards apply to trial courts for cases beginning after the date of the Act, and to appellate courts for cases fully submitted after the date of the Act. Parrish concerned the trial court; the case commenced long before the date of the Act. Amended section 455 therefore had no application to the case. 524 F.2d at 105 (Roney, J., specially concurring). The Fifth Circuit misconstrued the Act to mean that the amended provisions could be applied to the trial court if the appeal had not fully been submitted before the date of the Act. Cf. United States v. Haldeman, 559 F.2d 31, 130 n.284 (D.C. Cir. 1976) (en banc) (per curiam) (holding that amended section 455 had no application to the trial of a case beginning before the date of the Act, even though the appeal was filed after the date of the Act), cert. denied, 431 U.S. 933 (1977). See also Bradley v. Milliken, 426 F. Supp. 929, 932 (E.D. Mich. 1977); Duplan Corp. v. Deering Milliken, Inc., 400 F. Supp. 497, 505 (D.S.C. 1975).

4 524 F.2d at 101-02.

is Id. at 108. 
govern $^{46}$ and that the inquiry under section 144 should emphasize the "reasonableness of the litigant's fear" of bias rather than the actual state of mind of the judge. ${ }^{47}$

This interpretation seems wide of the mark: Admittedly, the affidavit must present the movant's reasons for doubting the judge's impartiality: it can do no more. The court's duty then is to judge whether those reasons suffice to "give fair support to the charge of a bent of mind that may prevent or impede impartiality of judgment." 48 The movant's fear is reasonable if the adduced facts reasonably support an inference that the judge is biased. The reference in the statute to "the belief" of the movant should not be interpreted as an adoption of the appearance-of-bias test.

The Parrish dissenters also argued that the appearance-of-bias test would best guarantee the integrity of the judicial process. They found the trial judge's involvement with a racially restrictive bar association and with the individual defendants sufficient to destroy the appearance of impartiality required of a judge..$^{49}$ They drew upon the 1974 amendment to section 455 to support their conclusion regarding the applicable standard. Since the new section 455(a) and its legislative history clearly embrace an appearance-of-bias standard, ${ }^{50}$ they argued, such a standard should govern all disqualification decisions. ${ }^{51}$ Moreover, the dissenters argued that sections 144 and 455 are only technically separate statutes: in practicality they are the federal courts' unified statutory structure of disqualification. The intent of Congress regarding that structure-whether expressed specifically in discussion of one or the other section-might sensibly be taken into account when deciding how both sections should be interpreted.

This use of the legislative history of section 455 is unpersuasive. Although the 1974 amendment to section 455 reflected a heightened congressional concern with the appearance of justice, section 144 was left unamended, and no attempt to alter the courts' use of a bias-in-fact test under that section appears in the legislative history. ${ }^{2}$ In fact, Congress rejected a proposed amendment of section

"Id. See also Parrish v. Board of Comm'rs, 505 F.2d 12, 20 n.9 (Tuttle, J.), vacated, 509 F.2d 540 (5th Cir. 1975).

${ }^{77} 524$ F.2d at 108 (quoting Note, Disqualification of Judges for Bias in the Federal Courts, supra note 4, at 1446-47).

4s Berger v. United States, 255 U.S. 22, 33-34 (1921).

1) 524 F.2d at 110-11 (Tuttle, J., dissenting).

so See text and notes at notes 60-65 infra.

s1 Id. at 107-10. Judge Tuttle said that his interpretation of section 144 is "fortified" by the 1974 revision of section 455 . Id. at 109 .

32 See United States v. Olander, 584 F.2d 876, 882 (9th Cir. 1978) (quoting Davis v. Board 
144 that would have explicitly made provision for a peremptory challenge procedure..$^{53}$ Adoption of an appearance-of-bias test for section 144 would, however, effectively implement such a procedure: since section 144 allegations must be accepted as true, litigants who are content to allege on "information and belief" might obtain disqualification on even the most specious grounds. ${ }^{54}$ It seems anomalous, therefore, to employ the legislative history of amended section 455 in order to reach a result explicitly rejected by Congress.

2. The Standard under Section 455 . Section 455 of the Judicial Code requires disqualification in the case of a judge's partiality. Subsection (a) of section 455 is broadly written and covers a wide range of situations, including bias and prejudice, in its general requirement that a judge "shall disqualify himself in any proceeding in which his impartiality might reasonably be questioned." Subsection (b)(1) of section 455 , by contrast, requires a judge to disqualify himself when "he has a personal bias or prejudice concerning a party." 56

The language of subsection (b)(1) is identical to the language of section 144 which, as previously discussed, has long been held to

of School Comm'rs, 517 F.2d 1044, 1052 (5th Cir. 1975) (en banc), cert. denied, 425 U.S. 944 (1976)).

ss 'Senator Bayh originally introduced a substitute for section 144 that would have allowed each litigant one peremptory challenge of a judge without any need to show or allege cause. S. 1886, 92d Cong., 1st Sess. (1971); Proposed Amendment to Broaden and Clarify the Grounds for Judicial Disqualification: Hearings on S. 1064 Before the Subcomm. on Improvements in Judicial Machinery of the Senate Comm. on the Judiciary, 93d Cong., 1st Sess. 6 (1971 \& 1973) [hereinafter cited as Senate Hearings]. Although this proposal received support from several commentators, see, e.g., Frank, Disqualification of Judges: In Support of the Bayh Bill, supra note 4, at 65; Comment, Disqualification of Federal District Judges-Problems and Proposals, supra note 4, at 635; Comment, Disqualification of Federal Judges for Bias Under 28 U.S.C. Section 144 and Revised Section 455, supra note 4, at 159, and had been employed with apparent success in some states, see Symposium, Disqualification of Judges for Prejudice or Bias-Common Law Evolution, Current Status, and the Oregon Experience, 48 ORE. L. REv. 311 (1969), the proposal proved controversial, largely because of its effect on districts with only one or two judges, and its perceived potential for abuse by litigants. See Senate Hearings, supra, at 18-19 (remarks of Senator Gurney). Thus, when Sentor Bayh reintroduced his amendment to section 455 in 1973, Senator Bayh indicated that though he still favored a peremptory system, he would save that battle for another day. Id. at 76 . The sponsors of new section 455 left no record of how they expected sections 144 and 455 to interact.

s4 Judge Gee has argued that this rule "gives free play to the unscrupulous or reckless affiant, willing to run his chance of a ponderous and unlikely prosecution for perjury." Parrish v. Board of Comm'rs, 524 F.2d 98, 105 (5th Cir. 1975) (en banc) (Gee, J., specially concurring), cert. denied, 425 U.S. 944 (1976). Judge Gee would substitute for it a rule that the judge "determine whether a given affidavit contains enough truth to fairly support a reasonable apprehension that he may be biased." Id. at 106.

ss 28 U.S.C. $\S 455(\mathrm{a})(1976)$.

ss Id. $\S 455(\mathrm{~b})(\mathrm{l})$. 
be governed by a bias-in-fact standard ${ }^{57}$ Congress was undoubtedly aware of the consequences of using identical language in both sections. Thus it seems appropriate to conclude-as have most courts $^{58}$ - that subsection (b)(1) is governed by a bias-in-fact standard. The more difficult issue is which standard-bias-in-fact or appearance-of-bias-governs section $455(\mathrm{a})$.

Subsection (a) of section 455 requires disqualification whenever a judge's impartiality may reasonably be questioned. ${ }^{59}$ This alone suggests that the appearance of bias is the appropriate standard of proof. This position is supported by the legislative history of section 455 and its Code of Judicial Conduct analogue, Canon 3C.

Amended section 455 had its origins in Canon $3 \mathrm{C}$ of the Code of Judicial Conduct. ${ }^{60}$ The Code can therefore serve as a reliable guide to interpreting the amendment. ${ }^{61}$ The drafters of the Code intended an appearance-of-bias test to govern Canon 3C. The Reporter's Notes state that "any conduct that would lead a reasonable man knowing all the circumstances to the conclusion that the judge's impartiality might reasonably be questioned is a basis for the judge's disqualification." 22 Moreover, the Notes explicitly refer to "participation by the judge in the proceeding [that] creates the appearance of lack of impartiality" ${ }^{63}$ as sufficient basis for disqualification under Canon 3C. The legislative history of the subsection similarly supports the use of an appearance-of-bias standard. Section 455(a) was designed to "promote public confidence in the impartiality of the judicial process"::44 "[1]f there is a reasonable factual basis for doubting the judge's impartiality, [the judge] . . . should disqualify himself." ${ }^{65}$

57 See text and notes at 34-37 supra.

ss Davis v. Board of School Comm'rs, 517 F.2d 1044, 1052 (5th Cir. 1975) (en banc) (the court failed to distinguish between subsections (a) and (b), interpreting them both in light of section 144), cert. denied, 425 U.S. 944 (1976); United States v. Baker, 441 F. Supp. 612, 618 (M.D. Tenn. 1977); United States v. Hall, 424 F. Supp. 508, 533 (W.D. Okla. 1975), aff'd, 536 F.2d 313 (10th Cir.), cert. denied, 429 U.S. 919 (1976). See also WRIGHT \& MiluER, supra note 4 , $\$ 3542$, at $345-46$ :

Since the key phrase in the new statute, "a personal bias or prejudice," is taken verbatim from Section 144, and there is nothing in the legislative history of the statute or of the Code of Judicial Conduct, from which it comes, to indicate to the contrary, it must be expected that decisions construing Section 144 will be thought controlling in interpreting this provision of Section 455.

31 See note 23 supra.

- See note 23 supra.

s1 See note 23 supra.

2 RePorter's Notes, supra note 18 , at 60.

is Id. at 61 .

4 House REPoRT, supra note 23, at 5, reprinted in [1974] U.S. Code Cong. \& AD. News 6355.

* Id. 
Not surprisingly, most courts have favored the appearance-ofbias test in cases involving section $455(a){ }^{66}$ The test is "not whether the judge is impartial in fact," but whether a reasonable man might doubt the judge's impartiality ${ }^{67}$ Adherence to an appearance-ofbias test has not been universal, however. Recently, in United States $v$. Olander, ${ }^{68}$ the Ninth Circuit rejected the appearance-ofbias test as the standard for disqualification under subsection (a) and held that a bias-in-fact test governed all motions for disqualification under section 455 .

The Olander court reasoned that, since section 455 was merely a statutory enactment of Canon $3 \mathrm{C}$, the latter was an authoritative guide to the new statutory provisions. The canon's structure, according to the court, set out a general standard for disqualification, then provided examples: the statute must be read as though section 455 (b)(1) were merely an example of what section 455 (a) was intended to cover. ${ }^{89}$ Therefore, the court concluded, "it would be incorrect, as a matter of statutory construction to interpret $\S 455$ (a) as setting up a different test for disqualification for bias or prejudice from that in $\S 455(b)(1) . " 70$

The court's conclusion is unpersuasive. The court relied upon the characterization of the phrase preceding subsection (b)(1)-a judge "shall also disqualify himself in the following circumstances"-as a "technical change" that could not justify two separate standards for disqualification for bias or prejudice. ${ }^{71}$ The legislative

s6 See, e.g., Rice v. McKenzie, 581 F.2d 1114 (4th Cir. 1978); United States v. Cowden, 545 F.2d 257 (1st Cir. 1976), cert. denied, 430 U.S. 909 (1977); Fong v. Amerian Airlines, Inc., 431 F. Supp. 1334, 1336 (N.D. Cal. 1977); Smith v. Pepsico, 434 F. Supp. 524, 525 (S.D. Fla. 1977); Bradley v. Milliken, 426 F. Supp. 929, 933 (E.D. Mich. 1977).

In the seminal case involving amended section 455, Parrish v. Board of Comm'rs, 524 F.2d 98 (5th Cir. 1975) (en banc), cert. denied, 425 U.S. 944 (1976) the court's interpretation of section 455(a) might be considered ambiguous. The dissent in Parrish treated the majority opinion as endorsing a bias-in-fact standard. Id. at 109 (Tuttle, J., dissenting). See also United States v. Zagari, 419 F. Supp. 494, 506 n.30 (N.D. Cal. 1976); 7 CumberLand L. Rev. 185, 191 (1976). The majority in Parrish rejected the section 455(a) claim on the grounds that it was not "supported by facts which would raise a reasonable inference of a lack of impartiality." 524 F.2d at 103-04 (Bell, J.). In its discussion preceding that conclusion, however, the court focused upon factors bearing on the appearance to the southern community of the judge's behavior. Moreover, that discussion is separate from, and more elaborate than, the discussion concerning the bias-in-fact standard under section 144. Compare id. at 101 with id. at 103-04. Thus, while the language of the opinion suggests a bias-in-fact standard under section 455(a), the substance of the court's inquiry was compatible with an appearance-ofbias standard.

${ }^{67}$ Rice v. McKenzie, 581 F.2d 1114, 1116 (4th Cir. 1978).

*s 584 F.2d 876 (9th Cir. 1978).

1d. at 882 .

io Id.

"Id. 
history of section 455 is, however, directly contrary: section 455 (a) was intended to establish grounds for disqualification distinct from those enumerated in subsection (b) (1).$^{72}$ That the grounds may overlap does not, in the face of clearly contrary legislative history, justify imposing the standards of subsection (b)(1) upon subsection (a).

A better approach to section 455 is found in the Tenth Circuit's opinion in United States $v$. Ritter ${ }^{73}$ At issue was the judicial behavior of Judge Willis W. Ritter. At the time of the case, the Utah Bar Association was considering resolutions for impeachment and other action against the judge. ${ }^{74}$ In the Ritter case the attorney for the defendants was then serving as President of the Utah Bar Association and as chairman of the committee evaluating the so-called "anti-Ritter" resolutions. As an apparent result, Judge Ritter was highly deferential to defendants' counsel, and contemptuous of the government's counsel. ${ }^{75}$

The Tenth Circuit analyzed the record and found that the judge's attitude did not "demonstrate" bias. ${ }^{76}$ Despite its finding of no "actual bias" on the part of the judge, the court decided that under the "broader" standard of section 455(a), ${ }^{77}$ disqualification was required..$^{78}$ That result is true to the language and spirit of section 455(a). It would have been troubling had the court followed the Ninth Circuit and concluded that, even though the judge's "impartiality might reasonably be questioned," he could not be disqualified because allegations of bias or prejudice, the basis of the doubts about the judge's impartiality, must be evaluated exclusively under the bias-in-fact standard of subsection (b)(1).

3. The Effect of Employing Different Standards of Proof. A judge is required to disqualify himself if, under any statute or canon, he is directed to do so. The strictest standard necessarily prevails. ${ }^{79}$ As a practical consequence, therefore, the bias-in-fact standard of section 144 will generally be irrelevant. A party fearing bias will make motions under all available statutes, but section 455 will al-

12 See House ReporT, supra note 23, at 5, reprinted in [1974] U.S. Code Cong. \& Ad. News at 6355 .

t3 540 F.2d 459 (10th Cir.), cert. denied, 429 U.S. 951 (1976).

"Id. at $460 \mathrm{n} .2$.

${ }^{75}$ Id. at $460-61$.

"Id. at 463 (emphasis added). The court divided its discussion into "whether the government has established actual bias" and "whether the total facts dictate the granting of relief."

$\pi$ Id. at 462 .

7 Id. at 464-65.

73 The Introduction to the Code of Judicial Conduct specifically provides that it will supercede any statute setting a less stringent standard for disqualification. 69 F.R.D. 273 (1975). 
most always govern. If the party can show bias in fact, then he will prevail under subsection (b)(1); if the party can show only an appearance of bias, he will prevail under subsection (a).

The application of different standards may have some significance. Section 144 , unlike section $455,{ }^{80}$ requires that allegations in affidavits supporting motions to disqualify be accepted as true. ${ }^{81}$ To the extent that litigants would abuse that requirement by making questionable factual allegations, the requirement that the allegations support a conclusion of bias in fact provides some protection for the courts. Allegations specific enough to support such a conclusion may also be more amenable to proof of falsehood in a subsequent disciplinary action or perjury prosecution against an attorney than the less substantial allegations of prejudice necessary under an appearance-of-bias standard. On the other hand, section 455 does not demand that allegations be accepted as true; a judge is at liberty to evaluate the truth, as well as the sufficiency, of allegations supporting a motion to disqualify under section 455 . Concerns with bad-faith litigant manipulation of disqualification rules are, therefore, less significant since the inaccuracy of allegations may justify a judge's refusal to disqualify himself under section 455(a). These differences allow the appearance-of-bias test to be applied, but in a manner that avoids the more obvious dangers of abuse attending the procedures of section 144 .

\section{B. The Perspective from Which to Evaluate Charges of Bias}

There are three possible viewpoints from which charges of bias might be evaluated. First, the judge might decide whether, in his own opinion, he should step down. This standard, applicable under section 455 until $1974,{ }^{82}$ has been rejected under the amended statutory framework: no person can be expected to evaluate disinterestedly his own fairness. ${ }^{83}$ Second, the charge might be evaluated from the perspective of the movant-presumably the person most sensi-

so It is possible that some courts will decide to hold evidentiary hearings under section 455. In the Watergate case, the ACLU, as amicus curiae, suggested that an evidentiary hearing be heard on the motion for disqualification of Judge Sirica. Mitchell v. Sirica, 502 F.2d 375, 378 (D.C. Cir. 1974), cert. denied, 418 U.S. 955 (1970) (MacKinnon, J., dissenting)." Judge MacKinnon supported this view. Id. On the Fifth Circuit, Judge Gee has urged that the presumption of truth of the allegations should be eliminated. Parrish v. Board of Comm'rs, 524 F.2d 98, 106 (5th Cir. 1975) (en banc) (Gee, J., specially concurring), cert. denied, 425 U.S. 94 (1976). Presumably, an evidentiary hearing would be required.

s1 See text and notes at notes 7-8 supra.

\$2 See note 9 supra.

s Cf. Berger v. United States, 255 U.S. 22, 36 (1921) ("To commit to the judge a decision upon the truth of the facts gives chance for the evil against which the section is directed."). 
tive to the possibility of bias. Although endorsed by some judges and commentators, ${ }^{84}$ this position has not been adopted by the courts. Instead, most courts have chosen a third option and concluded that the charge must be evaluated from the point of view of a reasonable, disinterested observer. ${ }^{85}$

The purpose of the appearance-of-bias test-to promote public confidence in the impartiality of the judicial system-is best served by adopting the viewpoint that is most likely to approximate public attitudes. Solicitude for the increased sensitivity of a litigant to arguably suspect judicial behavior would do little to foster such public confidence and could encourage the judge-shopping Congress intended to avoid.$^{88}$ The disinterested-observer perspective, on the other hand, facilitates the congressional purpose by focusing upon general public attitudes. It is clear, moreover, that Congress intended to minimize the impact of a litigant's peculiar fears on the disqualification process ${ }^{87}$ by adopting some version of a "reasonable person" test. ${ }^{88}$ The disinterested-observer perspective serves these goals.

The perspective of the reasonable, disinterested observer is not entirely unproblematic, however. In employing this perspective, achievement of the appearance of justice may require giving consideration to the reasonable fears of relevant subgroups in the population. In Parrish, for example, the largely white public-at-large might be much less suspicious of a judge who had recently presided over an all-white bar association than would a black citizen considering allegations of discrimination in the administration of a bar examination. ${ }^{89}$ The better approach in Parrish, therefore, would have been to evaluate the charges of bias from the perspective of a reasonable

s See, e.g., Parrish v. Board of Comm'rs, 524 F.2d 98 (5th Cir. 1975) (en banc) (Tuttle, J., dissenting), cert. denied, 425 U.S. 944 (1976); Note, Disqualification of Federal Judges for Bias Under 28 U.S.C. Section 144 and Revised Section 455, supra note 4, at 151.

ss See, e.g., SCA Servs., Inc. v. Morgan, 557 F.2d 110, 116 (7th Cir. 1977); Parrish v. Board of Comm'rs, 524 F.2d 98, 103 (5th Cir. 1975) (en banc), cert. denied, 425 U.S. 944 (1976); United States v. Baker, 441 F. Supp. 612, 617 (M.D. Tenn. 1977); Samuel v. University of Pittsburgh, 395 F. Supp. 1275, 1277 (W.D. Pa. 1975), vacated on other grounds, 538 F.2d 991 (3d Cir. 1976). The Second Circuit has declined to decide from which perspective the bias is to be judged. United States v. Daley, 564 F.2d 645, 651 n.7 (2d Cir. 1977), cert. denied, 435 U.S. 933 (1978); United States v. Wolfson, 558 F.2d 59, 64 n.15 (2d Cir. 1977).

$\varkappa$ House REport, supra note 23, at 5, reprinted in [1974] U.S. Code Cong. \& AD. News at 6355 .

"Id.

* Senate Hearings, supra note 53, at 93 (statement of Professor Thode, Reporter of the ABA Special Committee on Standards for Judicial Conduct).

sudge Tuttle, in dissent, applying the perspective of the movant rather than the disinterested observer, concluded that the judge should have been disqualified. 524 F.2d at 111-12 (Tuttle, J., dissenting). 
man sensitive to the concerns of black citizens. The addition of such flexibility to the disinterested-observer perspective would circumvent the troublesome feature of the reasonable-litigant perspective-that the increased sensitivity of the litigants may have no relationship to the actual effect of certain facts on the public view of federal tribunals-while foreclosing the possibility that disregard for the opinions of large minorities would create an appearance of bias.

\section{Extrajudicial Bias or Prejudice}

The "personal bias or prejudice" language of sections 144 and 455 (b)(1) has been interpreted to require that disqualifying bias "stem from an extrajudicial source." ${ }^{90}$ Attitudes developed as a result of a judge's participation in a case are generally treated as nondisqualifying, although in-court expressions of bias that are not otherwise related to the proceeding may justify disqualification. ${ }^{91}$ This limitation on the source of the bias that should result in disqualification has been held applicable to both statutes and the Code. ${ }^{92}$ The application of the limitation, however, seems incompatible with the language of section 455(a) and the goals of the 1974 amendments.

The rationale for the distinction between judicial and personal or extrajudicial bias rests upon a judge's obligation to reach judicial conclusions on the proceedings before him. Those conclusions ought not be taken as demonstrating "disqualifying" bias. Moreover, a consistent and predictable judicial philosophy demands that a judge have certain preconceptions on matters of legal principle, even though they may disadvantage a party.$^{93}$ Personal animosity

- United States v. Grinnell Corp., 384 U.S. 563, 583 (1966). See also Berger v. United States, 255 U.S. 22, 31 (1921); Ex parte American Steel Barrel Co., 230 U.S. 35, $43-44$ (1913); Craven v. United States, 22 F.2d 605, 607-08 (1st Cir.), cert. denied, 276 U.S. 627 (1927).

"See Wolfson v. Palmieri, 396 F.2d 121, 124 (2d Cir. 1968). See also Peacock Records, Inc. v. Checker Records, Inc., 430 F.2d 85 (7th Cir. 1970), cert. denied, 401 U.S. 975 (1971); WrIGHT \& MiLLER, supra note 4, § 3542, at $352-53 \& 353$ n.19. As the Wolfson court pointed out, the limitation applies to the source of the bias, not to the source of the evidence of the bias. Thus, "[c]omments and rulings by a judge during the trial of a case may well be relevant to the question of the existence of prejudice." $396 \mathrm{~F} .2 \mathrm{~d}$ at 124 . Some courts have mistakenly interpreted the rule to mean that disqualification may not be based on expressions of bias made by a judge during a proceeding. See Duplan Corp. v. Deering Milliken, Inc., 400 F. Supp. 497, 514 (D.S.C. 1975); Hirschkop v. Virginia State Bar Ass'n, 406 F. Supp. 721, 724 (E.D. Va. 1975).

"2 See cases collected in Wright \& MmLER, supra note 4, §3542, at $346 \mathrm{n} .10$ \& 1978 Supplement, at 188 n.10.

ss See Reporter's Notes, supra note 18, at 61; Proposed Amendment to Broaden and Clarify the Grounds for Judicial Disqualification: Hearings on S. 1064 Before the Subcomm. on Courts, Civil Liberties and the Administration of Justice of the House Comm. on the 
toward a party with an origin "beyond the four corners of the courtroom," 94 by contrast, has no place in the judicial decisionmaking process and must result in disqualification. ${ }^{95}$

1. Section $455(b)(1)$. The adoption of section 144's "personal bias or prejudice" language in subsection (b)(1) of section 455 suggests that Congress intended section $455(\mathrm{~b})(1)$ to cover the section 144 grounds for disqualification. If so, the interpretation of "personal" bias as including only bias with an extrajudicial source would apply to section $455(\mathrm{~b})(1)$. Indeed, this was apparently the result intended by the drafters of Canon $3 \mathrm{C}(1)(\mathrm{a})$, section $455(\mathrm{~b})(1)$ 's canonical analogue. Initially Canon $3 \mathrm{C}$ provided disqualification if a judge "had a fixed belief concerning the merits." That formulation was rejected, however, and the "personal bias or prejudice" language was adopted instead, in an effort to affirm the "necessity and value of judges having fixed beliefs about constituted principles and many other facets of the law." 97 This change indicates an intent to preserve the extrajudicial bias limitation. And since section $455(b)(1)$ was drafted to conform with Canon $3 C(1)$ (a), it seems reasonable to conclude that the extrajudicial bias or prejudice limitation applies to section $455(\mathrm{~b})(1)$ as well as to Canon $3 \mathrm{C}(1)(\mathrm{a})$.

The application of the extrajudicial-bias rule to subsection (b)(1) will be tempered by an increasing tendency to limit the rule. Courts have begun to disqualify judges who demonstrate biased attitudes in court, even though the judge's bias, if any, was a response to facts learned in the courtroom. ${ }^{98}$ The rule that is emerging focuses upon the quality of the bias, rather than its source. The Fifth Circuit has said, for example, that "where such pervasive bias

Judiciary, 93d Cong., 2d Sess. 11 (1974) [hereinafter cited as House Hearings] ("The provision is not as progressive as I personally would have wished since it does not reach possible bias or prejudice on an issue but only on parties.") (statement of John P. Frank).

" Sperry Rand Corp. v. Pentronix, Inc., 403 F. Supp. 367, 371 (E.D. Pa. 1975); United States v. Clark, 398 F. Supp. 341, 362 (E.D. Pa. 1975); United States v. Mitchell, 377 F. Supp. 1312, 1316-17 (D.D.C. 1974), aff'd sub nom. Mitchell v. Sirica, 502 F.2d 375 (D.C. Cir.), cert. denied, 418 U.S. 955 (1974).

ss The personal bias ground for disqualification does not serve to prevent a judge from continuing to sit in proceedings involving a party whom he has cited for contempt. United States v. Franks, 511 F.2d 25, 37 (6th Cir.), cert. denied, 422 U.S. 1042 (1975). Nor has it required the disqualification of a judge who may have formed an opinion concerning the guilt or innocence of a party at earlier trials or at trials of coconspirators. See United States v. Jeffers, 532 F.2d 1101 (7th Cir. 1976), aff'd in part, rev'd in part on other grounds, 432 U.S. 137 (1977).

* REPORTER's Notes, supra note 18, at 61.

"Id.; Anatonello v. Wunsch, 500 F.2d 1260, 1262 (10th Cir. 1974).

"s See, e.g., Bell v. Chandler, 569 F.2d 556 (10th Cir. 1978); Mims v. Shapp, 541 F.2d 415 (3d Cir. 1976). 
or prejudice is shown by otherwise judicial conduct as would constitute bias against a party, the bias or prejudice need not be extrajudicial in nature." 99

This apparent liberalization of the "bias or prejudice" grounds for disqualification is salutary. The judge must be free to draw conclusions from events in the courtroom and to act accordingly. Where events in the courtroom so incite him to personal hostility as to render him incapable of fair judgment on remaining issues, however, it is appropriate that he step down. ${ }^{100}$ When the appearance of justice is threatened, the extrajudicial bias limitation has reached the boundaries of its application.

2. Section $455(a)$. The legislative history of section 455 (a) suggests that it may have been intended to cover only extrajudicial bias. In testimony before the House Committee concerning the meaning of the new section 455 , the words "any proceeding in which his impartiality might reasonably be questioned" were described as "terms of art" to be interpreted in light of the experience with the ABA Canons. ${ }^{101}$ Specifically, they were "meant to cover the kind of thing where, for example, personal relationships are involved."102 Strictly read, this would suggest that the extrajudicial bias limitation has vitality under section 455 (a).

Such a strict interpretation, however, seems to accord neither with the language nor the purpose of the amendment. The extrajudicial bias limitation is a judicial gloss on the "personal bias or prejudice" language in sections 144 and 455(b)(1). Section 455(a) has no such language. The purpose of the section-to guarantee disqualification whenever a judge's impartiality might reasonably be questioned-suggests that disqualification is necessary regardless of the source of the appearance of bias. The extrajudicial bias limitation is therefore inconsistent with a standard primarily concerned with guaranteeing the appearance of impartiality.

A sensible interpretation of section 455 (a) is not likely to result in widespread disqualification for bias of a judicial nature. The normal course of judicial opinion-forming should not support a reasonable charge of bias since, insofar as a judge must form opinions on legal and factual questions, the ordinary observer would not

" Davis v. Board of School Comm'rs, 517 F.2d 1044, 1051 (5th Cir. 1975) (en banc), cert. denied, 425 U.S. 944 (1976); United States v. Baker, 441 F. Supp. 612,617 (M.D. Tenn. 1977).

100 Wolfson v. Palmieri, 396 F.2d 121, 121 (2d Cir. 1968) (dictum). See also Wright \& MiLLER, supra note 4, § 3542 , at 352 n.18.

101 House Hearings, supra note 93, at 14 (statement of John P. Frank).

102 Id. at 15. The primary thrust of Mr. Frank's answer was to ensure the congressmen that section 455(a) would not mean that judges could be "casually getting off the bench," or that parties could disqualify judges at will. Id. 
be likely to conclude that those opinions raise a reasonable doubt about a judge's impartiality. ${ }^{103}$ In this sense, then, the extrajudicial bias limitation will persist even under a broad reading of section 455(a). Still, courts applying section 455(a) have disagreed on whether the extrajudicial bias limitation should apply when the basis for disqualification is the appearance of partiality. An examination of the circumstances in which the limitation has been applied or rejected accentuates the inconsistency between the extrajudicial bias limitation and the congressional intent "to broaden . . . the grounds for judicial disqualification."104

Recently, in dictum, the District of Columbia Circuit concluded that the extrajudicial bias limitation applies to section 455(a). In United States $v$. Haldeman, ${ }^{105}$ the court reasoned that the legislative history does not indicate an abandonment of the limitation $^{108}$ and suggested that curtailing the limitation would have a "drastic" effect on the judicial process. ${ }^{107}$ This is a strained interpretation of the statute. The congressional judgment was that inconvenience to the judicial process should assume lesser importance than the guarantee of the appearance of justice. ${ }^{108}$ Moreover, the prediction of "drastic" consequences is unconvincing. As noted above, the normal course of judicial opinion-forming should not give rise to reasonable doubts about a judge's impartiality.

The facts of the case make the decision to extend the extrajudicial bias limitation particularly troubling. Appellants, Haldeman, Ehrlichman, and Mitchell, had moved for disqualification on the basis of activities by Judge Sirica that were primarily judicial in nature: ${ }^{109}$ statements in earlier trials-in reference to White House

${ }^{103}$ Cf. Mitchell v. Sirica, 502 F.2d 375, 379-80 (D.C. Cir.), (MacKinnon, J., dissenting) (discussing the circumstances in which judicially developed bias would or would not justify disqualification) cert. denied, 418 U.S. 955 (1974).

i's House REPORT, supra note 23, at 1, reprinted in [1974] U.S. CODE CoNG. \& AD. NEWS at 6351 .

${ }^{305} 559$ F.2d 31 (D.C. Cir. 1976) (en banc) (per curiam), cert. denied, 431 U.S. 933 (1977). Because the court found the case to be governed by the pre-1974 statute, id. at $130 \mathrm{n} .284$, the court's interpretation of the new section carries no precedential weight.

14 Id. at 132 n.297. The court derived support from the Fifth Circuit's en banc decision in Davis v. Board of School Comm'rs, 517 F.2d 1044 (5th Cir. 1975), cert. denied, 425 U.S. 944 (1976), which construed sections 144 and 455 in pari materia. Id. at 1052. The Davis court did not distinguish between section 455(b)(1), which should be interpreted in accord with section 144 , and section $455(a)$, which creates a new appearance-of-partiality ground for disqualification. To interpret new section 455 (a) as identical to section 144 is to deny that the 1974 amendment either broadened or clarified the disqualification statutes.

107 Id.

10s See generally House REPORT, supra note 23; House Hearings, supra note 93, at 114 (statement of John P. Frank).

in 559 F.2d at 133 n.301. 
personnel-that criminal liability extended to persons beyond the defendants there involved, statements to the press apparently prejudging venue issues, and ex parte contacts with the prosecution, among others. ${ }^{110}$ Although the court declared that Judge Sirica's conduct satisfied the appearance of impartiality standard, it is difficult to view the circumstances so complacently. It may fairly be said that "Judge Sirica's palpable search for truth . . . was . . . in the highest tradition of his office"111 and did not demonstrate any actual bias. But this search appeared to involve a preliminary conclusion about the merits of important factual issues and the very existence of criminal liability. ${ }^{12} \mathrm{~A}$ rigorous enforcement of the demand for the appearance of impartiality requires a less scrupulous adherence to the extrajudicial-bias limitation.

A recent Fourth Circuit decision, Rice $v$. McKenzie, ${ }^{113}$ has outlined an approach to the extrajudicial bias limitation that is more faithful to the spirit of section 455(a). The petitioner in Rice sought disqualification of the district court judge assigned to hear his habeas corpus petition on the grounds that the judge had been a member of the state supreme court that had previously rejected his claims. Although the circuit court concluded that the judge had "no personal bias or prejudice"114 against petitioner, it held that disqualification was required since "a reasonable person would have a reasonable basis for questioning [the judge's] . . . impartiality."115

The respondent in Rice contended that regardless of the appearance of partiality, disqualification could result only if the apparent bias "arose out of an 'extra-judicial' source."116 The Fourth Circuit rejected the respondent's contentions. Since the extrajudicial bias limitation was "grounded on the 'personal bias or preju-

10 Appellant's allegations are set out in $i d$. at $131 \mathrm{n} .293$. The allegations are discussed in more detail in Mitchell v. Sirica, 502 F.2d 375, 383-87 (D.C. Cir.) (MacKinnon, J., dissenting), cert. denied, 418 U.S. 955 (1974).

i1 559 F.2d at 138 n.346, (quoting United States v. Liddy, 509 F.2d 428, 442 (D.C. Cir. 1974) (en banc), cert. denied, 420 U.S. 911 (1975).

112 Id. at $131 \mathrm{n} .293$. Congress obviously intended such prejudgment to be disqualifying. "[W] here the judge [has] expressed an opinion about the merit or lack of merit of a specific case before such matter came before him . . . the judge [should] be disqualified." House Report, supra note 23, at 2, reprinted in [1974] U.S. CoDE Cong. \& AD. NEws at 6351. Moreover, Judge Sirica's earlier comments about the extent of criminal liability in the Watergate cover-up, coupled with his presence at the later trial, violated the maxim that "[n]o man may accuse and also sit in judgment." Mitchell v. Sirica, 502 F.2d 375, 385 (D.C. Cir.) (MacKinnon, J., dissenting), cert. denied, 418 U.S. 955 (1974). Judge MacKinnon presented a persuasive case for Judge Sirica's disqualification. Id. at 384-87.

is 581 F.2d 1114 (4th Cir. 1978).

iil Id. at 1115 .

11 Id. at 1116 .

III Id. at 1117. 
dice' language of other predecessor statutes," its applicability to section 455(a) was questionable. ${ }^{17}$ Even though the conduct that resulted in the appearance of bias in the case "was entirely judicial and not personal," it nevertheless supported disqualification under the broad section 455(a) requirement that a judge step down in the face of "a reasonable basis for questioning his impartiality."118

The Fourth Circuit's reasoning is persuasive. Section 455(a) is not limited in scope to extrajudicial partiality but is designed to ensure that any appearance of partiality is avoided. The principal goal of the extrajudicial bias limitation-allowing judges to perform their functions without fear that expressions of judicial opinions will result in disqualification-can be met by recognizing that such expressions of opinion rarely create a reasonable apprehension of unwarranted partiality.

\section{Bias Against Counsel}

Sections 144 and $455(\mathrm{~b})(1)$ are drafted to protect a litigant from "personal bias or prejudice either against him or in favor of the adverse party." 119 The language does not resolve the inevitable question whether a judge should be disqualified for bias against the litigant's counsel or in favor of the opposing counsel. In interpreting section 144, courts have split on the issue; the analogous problem under section 455 (a) also remains unresolved. ${ }^{120}$

There are several risks in allowing judicial bias against an attorney to be grounds for disqualification. Counsel might choose to seek disputes with a judge in order to obtain a different judge ${ }^{121}$-indeed, an attorney might obtain a type of "license" by which he could disqualify certain judges at will. ${ }^{122}$ Moreover, judges ought to be

117 Id.

IIs Id. at 1118.

II' See the text of section 144 reproduced at note 7 supra. Section $455(b)(1)$ replaces the phrase "either against him or in favor of an adverse party" with the words "concerning a party." See note 23 supra.

12 See Annot., 23 A.L.R.3d 1416 (1969 \& 1978 Supp.) (collecting state as well as federal cases).

121 Shakin v. Board of Medical Examiners, 254 Cal. App. 2d 102, 118-19, 62 Cal. Rptr. 274, 287 (1967), cert. denied, 390 U.S. 410 (1968).

12 In one case, an attorney seeking disqualification of a judge with a reputation for being strict with criminal offenders admitted that his practice would improve as a result of his ability to get the particular judge disqualified. "Judge Conti is a very strong sentencing judge," the lawyer said. "I can imagine a whole host of lawyers suddenly discovering that they need my able assistance in some cases so that they can ably assist Judge Conti out of the courtroom . . . ." He admitted that was one of the reasons he requested disqualification. United States v. Zagari, 419 F. Supp. 494, 505 (N.D. Cal. 1976). See also Davis v. Board of School Comm'rs, 517 F.2d 1044, 1050-51 (5th Cir.) (en banc), cert. denied, 425 U.S. 944 (1975). 
presumed to be capable of treating parties fairly even when they are "hostile" towards their counsel. A judge's ability to maintain decorum in his courtroom will depend on his freedom to rebuke wayward attorneys when necessary, and such signs of "hostility" not reaching the level of bias should not result in a judge's disqualification.

Most state and federal courts have accordingly ruled that bias against counsel is an insufficient ground for disqualification. ${ }^{123}$ Those courts that have treated such bias as sufficient grounds for disqualification have set a high standard. The Second Circuit, for example, requires disqualification only when the "antipathy has crystallized to a point where the attorney can do no right."124

The revision of section 455 invites a reappraisal of this problem. The new language of section 455(a) does not limit disqualification to bias for or against a party: it extends protection to all circumstances in which the judge's impartiality might reasonably be questioned. Moreover, subsections (b)(2) and (b)(5)(ii) of section 455 both require disqualification when the judge has certain, specifically defined relations with counsel. ${ }^{125}$ Plainly, Congress believed that relations with counsel could affect the fairness of a judge. It thus makes sense to acknowledge that same fact when evaluating the scope of the broader appearance-of-impartiality standard of section 455 (a). The integrity of the judicial system is best maintained when grounds for judicial disqualification include bias against counsel, for the observing public is not likely to distinguish between bias against a party and bias against counsel.

The difficult issue is, of course, determining whether a judge's bias for or against counsel has risen to such a level as to present the appearance of bias against a party or to be tantamount to bias against a party. Although in any case of bias against counsel the standard must be high, courts should be most willing to grant disqualification when the alleged bias is in favor of opposing counsel. In such circumstances there is no incentive for attorneys to create disputes with judges, no attorney can obtain a "license" to get a judge disqualified, and the power of the judge to control his courtroom is not impaired. In short, the risks associated with disqualifying judges on the basis of their contacts with attorneys are absent when the alleged bias is in favor of an attorney. United States $v$. Ritter $^{126}$ and Bell $v$. Chandler ${ }^{127}$ illustrate the circumstances in

\footnotetext{
123 See Annot., 23 A.L.R.3d 1416 (1969).

124 Rosen v. Sugarman, 357 F.2d 794, 798 (2d Cir. 1966) (dictum).

123 See note 23 supra.

124540 F.2d 459 (10th Cir.), cert. denied, 429 U.S. 951 (1976).

127 569 F.2d 556 (10th Cir. 1978).
} 
which bias towards counsel could warrant disqualification.

In Chandler the judge was disqualified because of his demonstrated hostility towards a United States Attorney. The judge and the attorney were described as engaged in "a legal tug-of-war."128 The court held that the judge's bias against the attorney was such that the United States itself was unlikely to obtain a fair trial. ${ }^{129}$ Similarly, in Ritter the Tenth Circuit disqualified Judge Ritter because of the judge's "caustic and curt" treatment of government attorneys and the judge's highly deferential treatment of a defense attorney. The Tenth Circuit doubted that the trial would be conducted "with the impartiality that litigants have a right to expect in a United States district court"130 and disqualified Judge Ritter in order "to avoid stress, trouble and complications in the upcoming trial."131 These cases demonstrate the wisdom of a rejection of the majority rule governing bias towards counsel. The philosophy of section 455 (a) requires protection for a party whose interests may be harmed by such bias.

\section{Procedural Aspects of Disqualification}

Section 144 establishes procedures for disqualification; section 455 , with the exception of its waiver provisions, does not. Some courts have concluded that section 144 supplies the procedural requirements for all motions to disqualify. ${ }^{132}$ Although such an interpretation makes sense of the existing statutory scheme, it creates a real danger that the stringent procedural rules that have developed around section 144 will mute the effect of the liberal disqualification standards of section 455 .

There are three reasons to reject the view that section 144 specifies the sole procedure for disqualification for bias or prejudice. First, section 144 remains on the books, not as part of a unified congressional plan for attacking the disqualification problem, but as the result of the inability of the sponsors of the 1974 amendments to push through a parallel amendment to section 144 that would

123 Id. at 559.

123 Id. at 560 .

$130540 \mathrm{~F} .2 \mathrm{~d}$ at 464.

ist Id.

132 See, e.g., Hawaii-Pacific Venture Capital Corp. v. Rothbard, 437 F. Supp. 230, 235 (D. Hawaii 1977); Fong v. American Airlines, Inc., 431 F. Supp. 1334, 1336 (N.D. Cal. 1977); Harley v. Oliver, 400 F. Supp. 105, 110 (W.D. Ark), vacated on other grounds, 538 F.2d 991 (8th Cir. 1976); Samuel v. University of Pittsburgh, 395 F. Supp. 1275, 1277 (W.D. Pa. 1975). See also School Dist. v. Missouri, 438 F. Supp. 830, 833 (W.D. Mo. 1977) (section 144 procedure applies only to motions to disqualify for bias or prejudice under section $455(b)(1)$ ). 
have radically altered its substance and procedure. ${ }^{133}$ The history of the two amendments belies any inference that section 455 was to be governed by the procedures of section 144 . Second, the genesis of section 455 in the Canons of Judicial Ethics suggests that it was intended to be self-enforcing. Judges are required to disqualify themselves when the statute so mandates, whether or not a party has moved for disqualification; ${ }^{134}$ no particular procedure need be followed to obtain disqualification. Finally, applying section 144 procedures to section 455 would require that any potentially disqualifying allegation be accepted as true. Under the stringent standards set forth in section 455 , such a requirement would render disqualification automatic upon request, contrary to congressional intentions. ${ }^{135}$

Nonetheless, the procedure established by section 144 will continue to influence the courts. Despite the fact that section 455 was intended to be self-enforcing, disqualification will usually be initiated by filing a motion for disqualification and affidavits alleging prejudice. The remainder of this comment will analyze the procedural problems of particular importance to judicial disqualification, eschewing a simple adoption of section 144 procedures and suggesting a flexible approach attuned to achieving the policies underlying the amended statute.

\section{A. Express Waiver}

One of the purposes of the 1974 amendments was to limit the possibility of waiver. Previous interpretations of section 144 and section 455 before its amendment had allowed parties to waive their rights to seek the disqualification of a judge. ${ }^{136}$ Congress felt that waiver defeated the purpose of the disqualification statutes: it was suggested that waiver permitted the judge to wield a "velvet blackjack." ${ }^{137}$ Counsel who would face a particular judge many times in his career would be hesitant to charge the judge with bias or to refuse a judge's request that he waive his right to disqualify. Senator

133 See note 53 supra.

13 See note 23 supra.

133 See note 53 supra.

t3s See Wright \& Miller, supra note 4, § 3553, at 382.

${ }^{157}$ Frank, Commentary on Disqualification of Judges-Canon 3C, supra note 4, at 387. Justice Traynor gave the following example of the use of the "velvet blackjack":

[W] here the judge says, I have, say, 10 shares of General Motors: Do you mind if I sit? And they fall all over each other to be the first one to say, "Oh, no, your honor." And you can see their fists clench below the desk and they are saying "The so and so should not put us in that spot."

House Hearings, supra note 93, at 20. 
Bayh explained that "no lawyer or party should have to be put in the position of indicating to a judge that he does not trust his ability to try the cause fairly. . . . [T] he lawyer . . . is likely to feel he must show his confidence in the judge by asking the judge to waive the disqualification." ${ }^{138}$

Congress did not, however, completely eliminate the possibility of waiver. Section $455(\mathrm{e})$ specifies that no judge may accept waiver of disqualification on any of the grounds specifically enumerated in section 455(b), but that disqualification based on the appearance of partiality in section 455(a) may be waived upon full disclosure on the record. Disqualification under section 144 may still be waived.

The possibility of waiver was arguably eliminated by amendment of the Code of Judicial Conduct. In 1975, the Judicial Conference deleted Canon 3D, which had permitted waiver; as a result, "a remittal of disqualification is [no longer] . . . permitted under any circumstances." 139 The Conference's action was somewhat ambiguous in that the change was made "to bring [the Code] into conformity with section 455 ." 140 Nevertheless, courts considering waiver since the 1975 revision have concluded that it is prohibited by the Code. ${ }^{141}$ The Code was amended again recently to bring it into conformity with the statutory waiver provisions. Thus, the congressional judgment to permit waiver of the broadest grounds for disqualification has been affirmed. ${ }^{142}$

\section{B. Timeliness and Implied Waiver}

Whether a motion for disqualification must be timely to be effective is a more difficult question. If a disqualification motion must be timely, then failure to move expeditiously results in loss of the party's right to seek disqualification. The result is often characterized as an implied waiver.

${ }^{138}$ Senate Hearings, supra note 53, at 12 (statement of Senator Bayh).

13969 F.R.D. 273, 279 (1975).

14 [1975] Admin. Ofpice of the United States Courts Ann. Rep. 12-13.

11 California v. Kleppe, 431 F. Supp. 1344, 1350-51 (C.D. Cal. 1977); Smith v. Sikorsky Aircraft, 420 F. Supp. 304, 307 (C.D. Cal. 1976); Wright \& MrLeR, supra note 4, $\S 3552$, at 201 (1978 Supp.).

112 The Code was amended at the meeting of the Judicial Conference on March 9-10, 1979 to read as follows:

D. Remittal of Disqualification:

A judge disqualified by the terms of Canon $3 C(1)$, except in the circumstances specifically set out in subsections (a) through (e), may, instead of withdrawing from the proceeding, disclose on the record the basis of his disqualification. If, based on such disclosure, the parties and lawyers, independently of the judge's participation, all agree in writing that the judge's disqualification should be waived, the judge is no longer disqualified and may participate in the proceeding. The agreement, signed by all parties and lawyers, shall be incorporated in the record of the proceeding. 
Section 144 requires that the affidavit supporting a motion to disqualify be "timely" and that it "shall be filed not less than ten days before the beginning of the term at which the proceeding is to be heard, or good cause shall be shown for failure to file it within such time."143 In 1963, Congress abolished formal terms for the district courts, depriving the timeliness requirement of any specific meaning. ${ }^{144}$ Courts have said that reasonable diligence is required in filing the affidavit, and that the challenge must be made at the first opportunity after discovery of the facts allegedly requiring disqualification unless good cause is shown for the delay. ${ }^{145}$

The timeliness requirement is an important guard against abuse: without it, a party could sample the temper of the court or even wait until after final judgment before deciding whether to file the affidavit. ${ }^{146}$ The timeliness requirement inhibits the use of disqualification as a delaying device and makes disqualification more likely at the beginning of litigation, thus sparing expense and delay.

Section 455 , in contrast to section 144 , has never specified any procedure for obtaining disqualification, ${ }^{147}$ though commonly a party has made a "motion for disqualification," often accompanied by affidavits. ${ }^{148}$ Prior to the 1974 amendments, most courts imputed a timeliness requirement in section $455 .{ }^{149}$ Courts have split on the question of a timeliness requirement in amended section 455 , with the majority requiring a timely filing. ${ }^{150}$

Neither the language nor the legislative history of the amended

t43 28 U.S.C. § 144 (1976).

14 Id. $\S 138$.

14s See Wright \& MiLLER, supra note 4, § 3551, at 379-80.

u' See, e.g., Roussel v. Tidelands Capital Corp., 438 F. Supp. 684, 691 (N.D. Ala. 1977); United States v. Hall, 424 F. Supp. 508, 534 (W.D. Okla. 1975); Duplan Corp. v. Deering Milliken, Inc., 400 F. Supp. 497, 509 (D.S.C. 1975) (section 144 only). See generally Skirvin v. Mesta, 141 F.2d 668 (10th Cir. 1944); Bumpus v. Uniroyal Tire Co. Div., 385 F. Supp. 711, 713 (E.D. Pa. 1974).

"17 United States v. Wolfson, 558 F.2d 59, 62 n.11 (2d Cir. 1977).

"s See, e.g., SCA Servs., Inc. v. Morgan, 557 F.2d 110, 112 (7th Cir. 1977).

u' Ramirez v. United States, 294 F.2d 277, 283 (9th Cir. 1961); Baker v. Mueller, 222 F.2d 180 (7th Cir. 1955). But see United States v. Amerine, 411 F.2d 1130 (6th Cir. 1969). Cf. William Cramp \& Sons Ship \& Engine Bldg. Co. v. International Curtiss Marine Turbine Co., 228 U.S. 645 (1913) (holding that rights under what is now 28 U.S.C. $\& 47$ (1976), prohibiting a judge to hear an appeal from a case he tried below, were not waivable); Rexford v. Brunswick-Balke-Collender Co., 228 U.S. 339, 345 (1913) (same).

${ }_{130}$ See, e.g., United States v. Daley, 564 F.2d 645, 651 (2d Cir. 1977), cert. denied, 435 U.S. 933 (1978); United States v. Grismore, 564 F.2d 929, 933 (10th Cir. 1977), cert. denied, 435 U.S. 954 (1978); United States v. Patrick, 542 F.2d 381, 390 (7th Cir. 1976), cert. denied, 430 U.S. 931 (1977); Satterfield v. Edenton-Chowan Bd. of Educ., 530 F.2d 567, 574 (4th Cir. 1976); Samuel v. University of Pittsburgh, 395 F. Supp. 1275 (W.D. Pa. 1975), vacated on other grounds, 538 F.2d 991 (3d Cir. 1976). But see Barry v. United States, 528 F.2d 1094, 1098 n.7 (7th Cir. 1976); Bradley v. Milliken, 426 F. Supp. 931 (E.D. Mich. 1977). 
statute indicates whether the timeliness requirement is retained under the 1974 revision. During the congressional deliberations the Department of Justice recommended that the new section 455 include a time limitation "to prevent applications for disqualification from being filed near the end of a trial when the underlying facts were known long before." 151 Congress did not adopt this suggestion, leading one court to conclude that it had rejected a timeliness requirement. ${ }^{152}$ On the other hand, Congress's failure to act could as easily have been the result of a belief that the judicial gloss on old section 455 would survive.

There are two reasons why a timeliness requirement may be incompatible with the purpose of amended section $455 .{ }^{153}$ First, a timeliness requirement would vitiate the limitation on express waiver by permitting implied waiver. Congress sought to remove from the judge the power to coerce waiver; a timeliness requirement could provide a more subtle method of waiver, without the full disclosure normally required when waiver is allowed.

This argument has little force when applied to section 455(a), which apparently permits waiver. Even when applied to section $455(\mathrm{~b})(1)$, the argument is unconvincing. Waiver by delay is not likely to be the product of a judge's suggestions and, therefore, lacks the coercive potential of express waiver. Moreover, abolition of the timeliness requirement would probably have minimal effect upon the incidence of implied waiver since an attorney reflecting upon years of future practice before a judge may hesitate to challenge the judge's impartiality at any point in the proceedings. Finally, without a timeliness requirement, a well-meaning attorney might be encouraged to wait as long as possible-even until after final judgment ${ }^{154}$ - to challenge the judge. A timeliness requirement reduces incentives for delay and promotes full disclosure and discussion. The integrity and effectiveness of the judicial process stands to gain as a result..$^{155}$

151 House REPORT, supra note 23, at 9, reprinted in [1974] U.S. Code.Cong. \& AD. NEws at 6358.

132 SCA Servs., Inc. v. Morgan, 557 F.2d 110, 117 (7th Cir. 1977).

iss See text and notes at notes 21-30 supra.

134 Courts have sometimes held that a party may not raise the issue of disqualification upon appeal if he did not raise it in the court below. United States v. De La Fuente, 548 F.2d 528 (5th Cir. 1977), cert. denied, 431 U.S. 932 (1977); United States v. Foddrell, 523 F.2d 86, $87 \mathrm{n.2}$ (2d Cir.), cert. denied, 423 U.S. 950 (1975). Although this is a sensible conclusion from a practical perspective, it does not accord with an absolute prohibition on waiver.

iss A timeliness requirement could interfere with the goal of maintaining the appearance of impartiality. The public is not likely to be convinced that a judge is any less biased merely because the facts that cast doubt upon his impartiality were not complained about until well into the proceeding. On the other hand, it might legitimately be asked whether the spectacle 
The more persuasive argument against a timeliness requirement is formal: the self-enforcing character of section $455^{156}$ is simply incompatible with waiver by delay. Section 455 provides that the judge "shall disqualify himself" in certain specified situations. The language is mandatory: when a judge learns that grounds for his disqualification exist under section 455 , he must stand down, regardless of the source of the information or the time when he becomes aware of it. ${ }^{157}$

Thus, the Seventh Circuit recently issued a writ of mandamus ordering the district judge to disqualify himself in the midst of litigation, even though both parties knew of the disqualifying facts many months before taking action. ${ }^{158}$ The court concluded that, since the provisions of section 455 are addressed to the judge, "[t]hey impose no duty on the parties to seek disqualification nor do they contain any time limits within which disqualification must be sought." 158 Any judicially imposed time limitation, the court argued, "would frustrate the purpose of the statute."160

Yet the usefulness of a timeliness requirement in many cases is undeniable. Where the bias is clear or egregious, disqualification should be granted at any time. Where the grounds for disqualification are tenuous-where only a punctilious attention to the niceties of the appearance of impartiality would require disqualification-the cost to the system, including the appearance of injustice caused by manipulative attorneys, is greater than the gain.

Perhaps the only means of reconciling the usefulness of a timeliness requirement with the structure of section 455 is to impute a timeliness requirement into the "reasonableness" language of section 455(a). In United States v. Daley, ${ }^{181}$ for example, the Second Circuit affirmed a conviction against an appeal based partly on the trial judge's refusal to disqualify himself. The defendant had waited

of an attorney dragging his opponent through a long and costly proceeding, only to conclude by moving for disqualification of the judge, is not equally detrimental to public impressions of the judicial systern.

150 Parrish v. Board of Comm'rs, 524 F.2d 98, 102 n.8 (5th Cir. 1975) (en banc), cert. denied, 425 U.S. 944 (1976); Davis v. Board of School Comm'rs, 517 F.2d 1044, 1051-52 (5th Cir. 1975) (en banc), cert. denied, 425 U.S. 944 (1976); United States v. Baker, 441 F. Supp. 612, 617 (M.D. Tenn. 1977). See also 120 Conc. Rec. 36, 269 (1974) (remarks of Rep. Kastenmeier).

${ }^{157}$ In a different context, the Supreme Court has commented that "it would be a strange rule which deprived a judge of power to do what was asked when request was made by the person most concerned, and yet allowed him to act without petition." United States v. Smith, 331 U.S. 469, 474-75 (1947).

1ss SCA Servs., Inc. v. Morgan, 557 F.2d 110, 117 (7th Cir. 1977).

153 Id.

16 Id.

161564 F.2d 645 (2d Cir. 1977), cert. denied, 435 U.S. 933 (1978). 
until ten days into the trial to move for disqualification. His motion was based upon facts in the public record of an earlier proceeding. Although the motion presented a colorable claim of an appearance of bias, ${ }^{102}$ the court held that, given the defendant's delay in making his motion, he could not maintain that the judge's impartiality could "reasonably be questioned."163

The self-enforcing character of section 455 seems clearly incompatible with a timeliness requirement. Yet, in the absence of such a requirement, the danger of attorney delay is significant. The problem may be attributed to Congress's failure to think in procedural terms. A self-enforcing, nonwaivable requirement of disqualification appeals to high-minded sensibilities, but in a legal world where rules are manipulated for litigious advantage, such highmindedness creates a disruptive muddle. It might be possible to recreate order by imputing a timeliness requirement for motions under section 455(a): since the Judicial Code affects explicit waiver only and since explicit waiver is statutorily permitted, implied waiver is also permitted. This would solve the problem in most cases; but, for the statute to be read with full consistency, amendment would be required, replacing the unworkable notion of selfenforcement with clear procedural rules. In the absence of such an amendment, the courts should impose no timeliness requirement on section $455(\mathrm{~b})(1)$ motions, while balancing the apparent injustice caused by the attorney's delay against the apparent judicial bias to determine whether disqualification is appropriate under section $455(a) .{ }^{184}$

\section{Transfer of a Motion to Disqualify}

For some observers, a judge's evaluation of his own impartiality inevitably appears suspect. One solution to the problem would be to transfer disqualification motions to another judge for decision. Where possible, such a transfer would produce a more disinterested decision and a greater appearance of fairness. It would also spare the challenged judge the embarrassment of ruling on his own impartiality. On the other hand, a policy of automatic transfer would be a potent weapon for disruptive delay in the hands of a "daring and

112 Id. at 651.

is Id.

II Since a balancing approach would serve the goal of promoting the appearance of justice, it is not entirely at odds with the purpose of the statute. Moreover, the legislative history suggests that some discretion remains with the judge who must rule on a motion to disqualify. See House REPORT, supra note 4, at 5, reprinted in [1974] U.S. CoDE CoNG. \& AD. News at 6355. 
unscrupulous" party. ${ }^{165}$ Such disruption would be particularly acute in states or territories with only one or two federal judges. ${ }^{166}$ Moreover, the challenged judge, being most familiar with his own conduct and with the posture of the litigation, is in the best position to protect the court and opposing parties from groundless or dilatory disqualification motions.

These arguments notwithstanding, under most circumstances transfer of a motion to disqualify is the better procedure. ${ }^{167}$ Although the decision to transfer must be left to the discretion of the challenged judge, courts of appeals should exercise their supervisory authority ${ }^{188}$ in favor of transfer in all cases except where the danger of delay and disruption is substantial.

The policy against automatic transfer is so firmly imbedded in court practice, however, that it is sometimes seen as precluding any transfer. ${ }^{160}$ The possibility of referring section 144 disqualification motions to another judge for decision has been described as "utterly foreign to the statutory scheme." 170 Nevertheless, precedent does exist for such referral ${ }^{171}$ and a variety of procedural devices allow such transfer in the face of a statutory scheme and court prece-

is See Parrish, 524 F.2d at 107 (Gee, J., specially concurring).

I6 United States v. Zagari, 419 F. Supp. 494,499 (N.D. Cal. 1976). The states are listed in id. at $499 \mathrm{nn} .8$ \& 9 . The recent increase in the number of federal judges may do much to alleviate this concern.

107 In 1961, the Judicial Conference of the United States passed a recommendation that motions under section 144 be transferred to a different judge to rule on the sufficiency of the affidavit. [1961] Judicial Conf. of the United States ANN. Rep. 68-69. One commentator has recommended that the motion be heard by the appellate court directly. Note, Disqualification of Judges for Bias in the Federal Courts, supra note 4, at 1439.

113 The courts of appeals have the authority to set "standards far more rigorous than those set by the Constitution or by federal statute." United States ex rel. Perry v. Cuyler, 584 F.2d 644, 645 (3d Cir. 1978).

II' E.g., United States v. Bell, 351 F.2d 868, 878 (6th Cir. 1965), cert. denied, 383 U.S. 947 (1966).

170 Parrish, 524 F.2d at 106 (Gee, J., specially concurring). Such references could not be made under the old section 455 , which required the judge to disqualify himself if "in his opinion" he met the statutory standards. 28 U.S.C. $\$ 455$ (1970).

171 In United States v. Grinnell Corp., 384 U.S. 563, 582 n.13 (1966), the Supreme Court mentioned without adverse comment that the disqualification motion below was referred to a different judge. Several lower courts have used the procedure. See, e.g., Rademacher v. City of Phoenix, 442 F. Supp. 27 (D. Ariz. 1977); Bradley v. Milliken, 426 F. Supp. 929 (E.D. Mich. 1977); United States v. Zagari, 419 F. Supp. 494, 497 (N.D. Cal. 1976); Tenants \& Owners in Opposition to Redevelopment v. Department of HUD, 338 F. Supp. 29, 31 (N.D. Cal. 1972). The District of Columbia Circuit has discouraged the practice of transfer, calling it "at most permissive." United States v. Haldeman, 559 F.2d 31, 131 (D.C. Cir. 1976) (en banc) (per curiam), cert. denied, 431 U.S. 933 (1977).

172 Where a judge is regarded as obliged to rule on the motion for his disqualification, creative courts have circumvented the rule. An exception has been suggested for situations in which the judge "feels that by [transferring the motion] he might better assist in the promotion of public confidence in the impartiality of the judicial process." Hawaii-Pacific 
dent $^{172}$ that envisions self-disqualification by judges. Gradually, exceptions that allow transfers to promote "public confidence" may swallow the rule. There is no reason to delay that development. Section 455 specifies no procedures for handling motions to disqualify; upon presentation of such motions, judges could routinely transfer them to another judge for decision. Although the section requires the judge to disqualify himself, it does not demand that he evaluate the propriety of doing so. Such a straightforward procedure would retain discretion to refuse transfer when the result would be undue delay. In the majority of cases, moreover, the transfer would assist courts in attaining the goal of a disqualification system that operates-and appears to operate-fairly.

\section{ConcLusion}

The 1974 amendments to section 455 of the Judicial Code have left a certain degree of confusion in their wake. The amendments have essentially accomplished their purposes of eliminating the erstwhile "duty to sit," substituting the objective viewpoint of the reasonable man for the prior subjective viewpoint of the judge in evaluating motions for disqualification, and introducing an appearance-of-bias ground for mandatory disqualification. Nevertheless, the uncertain relationship between section 455 and section 144 of the Code, which remained in force unamended, has resulted in a conflicting and sometimes contradictory statutory scheme.

The courts, moreover, have lagged in implementing all of the congressionally mandated changes in the scope of judicial disqualification under section 455 . Given the clear indication in both the statutory language and the legislative history that Congress intended to establish more effective standards for disqualification, the argument for reassessing the application of the statute is compelling. The primary focus must be upon the need for a judicial system that not only is impartial in fact, but also appears to render disinterested justice; the administrative concerns of potential increases in judicial disqualification merit only secondary consideration. The courts should strive to interpret section 455 in a manner that preserves broad substantive grounds for disqualification, thereby vindicating the public's right to an unsullied judiciary, but imposes pro-

Venture Capital Corp. v. Rothbard, 437 F. Supp. 230, 236 (D. Hawaii 1977) (following Berger v. United States, 255 U.S. 22, 36 (1921)). Another court chose to pass on the motion, but immediately submitted it to another judge for reconsideration. United States v. Zagari, 419 F. Supp. 494, 499 (N.D. Cal. 1976). 
cedural limitations to ensure that the precepts of judicial ethics are not twisted into mere instruments for litigious advantage. This comment has suggested an approach to the existing statutory framework designed to strike an appropriate balance between these concerns. 